\title{
SLUDGE TREATMENT FOR APPLICATION IN AGRICULTURE SHOULD BE THE OPTION NUMBER ONE FOR UKRAINE
}

\author{
Lidiia Svirenko \\ Viktoriia Bondar \\ National Academy of Municipal Economy Kharkiv, Ukraine
}

\begin{abstract}
Ukraine is well-known in the world as a country with soil rich for humus. Approximately $68 \%$ of arable soils in Ukraine have been classificated as chernozem. For last decades decrease of organic matter content in soils of various agri-climatic zones has been surveyed in the country. The main reason of the mentioned process is enormous lack of organic fertilizer (manure) in agriculture connected with decrease in livestock (in 3 times since year 1992). Besides there is expansion of technical crops for biofuel production (like Brassica napus, Helianthus annuus), which are the provocateurs of soils exhaustion.

At the same time such important source of organic matter for application in agriculture as sewage sludge (SS) from wastewater treatment plant (WWTP) is not used in Ukraine nowadays. To stop arable soils degradation in regions it is necessary to develop up-to-date management for fertilizer production on WWTPs. The base for the process has to be the acceptance of the goal-oriented National programme, corresponding governmental decrees and implementation of national standard for using sewage sludge as fertilizer.
\end{abstract}

\section{KEY WORDS}

Sewage sludge; Soil degradation; Fertilizer; Agriculture; Standards for sewage sludge application; Ukraine

\section{INTRODUCTION}

Sewage sludge is the largest by-product from waste water treatment plants (WWTP) and its disposal is one of the most challenging environmental problems in waste water treatment processes. There are in the world some methods for sewage sludge treatment which are currently used, i.e. recycling in agriculture, landfilling, burning and incineration, destroyed land restoration $[1,2,3,10]$.

Recycling sewage sludge into fertilizer for agricultural purposes may improve soil fertility by influencing the physical, chemical, and biological properties of the land. Sewage sludge is land applied to improve the structure of the soil. The solids in the sludge contain nutrients of value to plants, as well as humus-like material which improves the capacity of poor soils to hold water and air. It is known, that fresh sewage sludge possess high physiological activity, which decrease with time. Effectiveness of sewage sludge as a fertilizer depends on its chemical composition, applying doze, plant growth phase, its specie

https://doi.org/10.15626/Eco-Tech.2010.037 
and age $[8,10]$. Advantages for growers in USA and Canada of using SS as fertilizer are as follows [5, 7, 9]: 1) sludge can be used alone or as a supplement to commercial fertilizers; 2) it can be obtained at a little or no costs; 3) sludge can be easily obtained because of short distance to nearest water treatment work.

Heavy metals, organic pollutants and pathogens concentrated in sewage sludge during wastewater treatment are the main obstacles to land application of sewage sludge. Instead of the obstacles municipal sewage sludge can be used as fertilizer and biostimulator for decorative crops, rolled root-mats production, tree nursery [10,4]. There is an opinion that, due to less heavy metals contamination of present sewage sludge, fertilization of same areas leads to decreasing of heavy metals concentration in soils. In Chicago city (USA) stabilized sewage sludge is used for destroyed land restoration, in doses, which are greatly exceeded national norms [6]. Utilization of sewage sludge in mining for process of destroyed land recultivation has been proposed in Russian and Belorussia [11]. Positive aspects of sewage sludge for substrate application are the improvement of such properties as $\mathrm{pH}$, organic matter content, porosity, cation exchange capacity, and water retention and movement $[11,5,1]$.

The option for SS utilization as burning allows using this waste for energy production. In USA, Germany, Netherlands, Japan and many others countries hundreds units of special equipment are in operation for energy production using sewage sludge as a fuel. Problem is a way for treatment of ash produced in the processes of burning or incineration $[1,7]$.

According to the report of the EU Commission of 19 July 2006 on implementation of the Community waste legislation, using sewage sludge as fertilizer on agricultural soils remains one of the best environmental options, provided it poses no threat to the environment or to animal and human health. Seven Member States report using at least 50\% of the sludge they generate in agriculture [13].

Countries can choose the priority utilization method taking into account environmental, economic, resource-saving and social aspects of this issue. In Ukraine there is no modern technologies for sewage sludge utilization, the most common is storage on sludge fields. It leads to removing sizeable areas from general use and to negative environmental impact. The object of the proposed study is determination of issues for sewage sludge application in agriculture according to condition of Ukraine.

\section{MATERIALS AND METHODS}

Ukraine (population 46 million) is an East European country situated on the East European plains (95\% of the territory), Ukrainian Carpathian Mountains and Crimean Mountains. Latitudinal geographic belts in Ukraine change from mixed forests on the north to steppes on the south of the country. There are nearly 40 types of soils in Ukraine all in all which. could be divided into three major groups: sandy podzolized soils and grey forest soil on the north; black Ukrainian chernozem known as a most fertile soil covering two thirds of total area; and chestnut and salinized soils on the south [14]. Cereals, sunflowers and beetroot are the main cultivations in the agriculture of the country. Pork and lard is traditional production of Ukraine and livestock farms one could see as common element of economies in rural areas.

Insufficient fertilization, intensification of industrial crops growing, processes of soil degradation, all these lead up to the process of overmineralization of humus in soils. In the same time in the most regions of Ukraine there are such stable sources of organic matter as wastewater treatment plants. Sewage sludge contains high levels (above $60 \%$ ) of organic matter and is rich in nitrogen and phosphorus which are essential elements for plant growth [1]. 
This study was carried out mainly using materials of Kharkiv region. Kharkiv $(1,500,000$ inhabitants) is a city located on a rolling plain in the Forest-Steppe zone in north-eastern Ukraine. The prevailing types of soil are chernozems and gray forest soils in the region. $79 \%$ of Kharkiv region is occupied by agricultural lands. Kharkiv is the city with developed industries, such as machinery, mechanical, electrical, electronic engineering and pharmacies and large scientific center too [15]. Mixed municipal and industrial wastewater is treated at two municipal WWTPs («Dikanivka» and «Bezludivka») with a total capacity of 1,000,000 $\mathrm{m}^{3} /$ day. The WWTPs perform full mechanical and biological treatment of wastewater. Further treatment of thy sludge generated by both WWTPs is carried out at the «Bezludivka» WWTP. The annual volume of sludge to be treated is mire then $1,000,000 \mathrm{~m}^{3}$ (about $3000 \mathrm{~m}^{3} /$ day). Sewage sludge is passed through thickeners and decanters (centrifuges). Dewatered sludge contains about $15 \%-20 \%$ in solids $[18,19]$. Special ponds on sludge fields are used on WWTP «Bezludivka» for dewatering of sewage sludge as emergency facilities and about $20 \%$ of the total sludge volume are treated there [12]. Bringing into service the installation for dewatered sludge drying is in active preparation.

Analyses of the world experience in the field of sewage sludge management and Acts for regulation it application as a fertilizer in environment friendly way have been carried out and statistic data concerning Ukraine were examined for determination of preferable for Ukraine methods of sewage sludge treatment.

\section{RESULTS AND DISCUSSION}

\subsection{Properties of agriculture soils}

Ukrainian soils have been loose more than $8.5 \%$ of total humus reserve since 1980. From one hectare of agricultural land up to 0.5-0.6 ton of humus is lost annually [14]. Use of heavy agricultural technical equipment in Ukraine is the weightily factor of intensification of soil erosion because of affection soil structure destroyed and expose to compaction. It has been estimated in experiments the density of arable layer increased in 1.2 times after heavy tractor's passing [16].

Organic matter is the main factor in forming and stability of durable soil structure and intensification of industrial crops growing for the last decade affected decreasing of humus content in soil too.

\subsection{Fertilizers applying}

Loss of nutrients in soils of Kharkiv region reaches $100 \mathrm{~kg} /$ hectare. According to agronomic recommendations 10 tons of fertilizers have been applied per 1 hectare of agricultural land, but in last years real quantity of fertilizers applied was only 1.5-2.5 tons/ha [24, 15]. In Zaporizhsky region (zone of Steppe) in 1990 was applied 6-7 ton/ha and in 2003 - only 0.47 ton/ha It's impossible to provide deficite-free humus balance in soils with such kind of fertilization. 


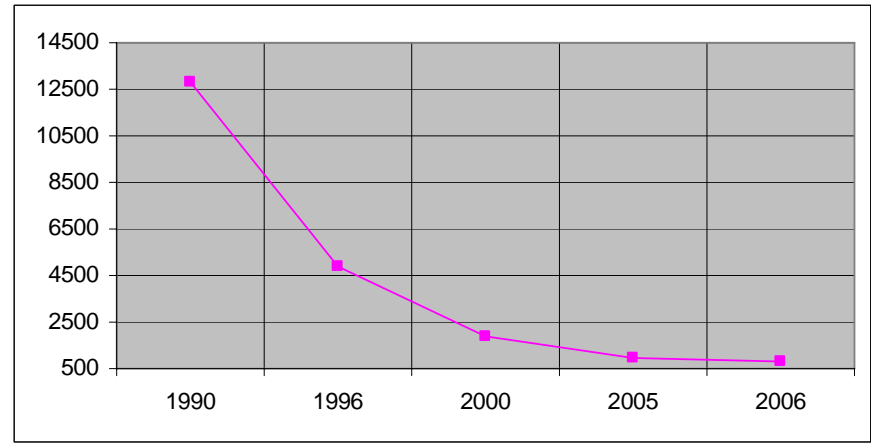

Figure 1. Dynamics of fertilizer applying in Kharkiv region (organic matter, thousand $t$ annual) [24].

Usually manure is the main source of organic matter for fields, and just decrease of livestock number since the year of 1992 (see Figure 2) resulted in enormous lack of organic fertilizer in agriculture of Ukraine.

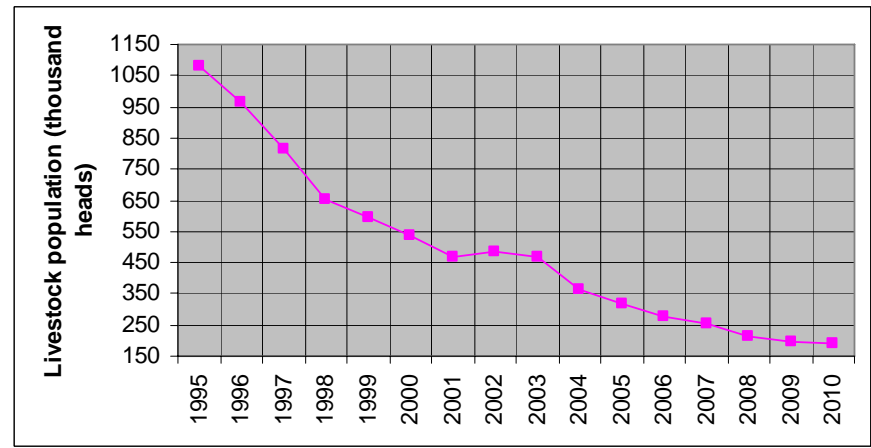

Figure 2. Livestock number in Kharkiv region (thousand heads) [15].

Taking into account the situation described above, obviously, that it is necessary to increase organic fertilizers production, including unconventional ones like sewage sludge.

\subsection{Quality of «Bezludivka» WWTP sewage sludge as fertilizer}

Due to theoretical estimation of compounds of biomass in active sludge correlation of the elements could be expressed by formula $\mathrm{C}_{1} \mathrm{H}_{1.619} \mathrm{O}_{0.379} \mathrm{~N}_{0.246} \mathrm{P}_{0.022} \mathrm{~S}_{0.004}$ [17]. So and sewage sludge is rich not only in organic matter but in nitrogen and phosphorus being the essential elements for plant growth. Ash content in SS mechanically dewatered on WWTP is $38-25 \%$. It gives the one more evidence of high organic matter content in sludge too.

The data concerning characteristics of the sample of SS from «Bezludivka» WWTP may be given as follows: organic matter $-16.1 \%$, nitrogen total $-3.0 \%$, phosphorus - up to $3.6 \%$, $\mathrm{pH}$ value $7.2[16,18]$. Trace elements content in sludge and limits for the elements according regulations of Russia and EU are given in table 1. Ukraine for the moment has no normative documents, which can provide standard for environment friendly utilization of sewage sludge. 
Table 1. Trace element content in sewage sludge, $\mathrm{mg} \mathrm{kg}^{-1} \mathrm{DM}$

\begin{tabular}{|c|c|c|c|c|}
\hline Element & $\begin{array}{c}\text { «Bezludivka» } \\
\text { WWTP } \\
{[]}\end{array}$ & \multicolumn{2}{|c|}{$\begin{array}{c}\text { Limit values } \\
\text { GOST R 17.4.3.07-2001 [21] }\end{array}$} & $\begin{array}{c}\text { 86/278/EEC } \\
{[20]}\end{array}$ \\
\cline { 2 - 4 } & 30 & Type I & Type II & \\
\hline $\mathbf{C d}$ & 815 & 15 & 30 & $50-40$ \\
\hline $\mathbf{C r}$ & 329 & 500 & 1000 & $1000-1750$ \\
\hline $\mathbf{C u}$ & 15 & 750 & 1500 & - \\
\hline $\mathbf{H g}$ & 230 & 7,5 & 15 & $300-400$ \\
\hline $\mathbf{N i}$ & 40 & 200 & 400 & $750-1200$ \\
\hline $\mathbf{P b}$ & 1050 & 1750 & 500 & $2500-4000$ \\
\hline $\mathbf{Z n}$ & 7,2 & $5,5-8,5^{*}$ & $5,5-8,5^{*}$ & \\
\hline $\mathrm{pH}$ & & 250 & 3500 & \\
\hline
\end{tabular}

*Sewage sludge with $\mathrm{pH}$ above 8.5 may be used as a fertilizer for acidic soils [21]

According to the standard of Russian Federation for sewage sludge application as fertilizers we can conclude that the total heavy metals content in sewage sludge produced on «Bezludivka» WWTP meet the requirements for fertilizer type II, which is recommended to apply for cereal and industrial crops and for urban plantation and nursery.

\subsection{Legislation and requirements}

In Ukraine there is no State standard for sewage sludge application in agriculture for the moment. Technical Requirements [22] worked out in the beginning of $90^{\text {th }}$ years of the last century have not been valid for more than ten years. EU ore RF standards did not implement in Ukraine too.

Meanwhile the sanitary limits for contaminants content concerning heavy metals in agricultural soils are in force in Ukraine [23]. They can serve as the base for calculation of sewage sludge quantity to apply on field taking into account a heavy metal concentration in SS and in soil too.

Implementation of the Standard for sewage sludge characteristic as fertilizer integratively with technique for calculation of permissible fertilizer quantity applying per square unite would make it real to use SS in agronomy in Ukraine without damage for the health of agricultural production consumers.

\section{CONCLUSION}

Analysis of agricultural soil quality in different agro-climatic zones of Ukraine proofed the process of soil degradation in the country. Erosion and loss of humus from soils are provoked not only by natural factors but using in agriculture heavy technical equipment and expansion of technical crops for biofuel production too. Insufficient fertilization mainly for decreasing in times livestock number and manure applied on land results in soil exhaustion

Meanwhile huge volume of sewage sludge being promising fertilizer is accumulated on WWTs in many cities and municipalities of Ukraine. Using sewage sludge as fertilizer in agriculture based on high organic matter content is the best option for the country. 
In order to realise this way of SS disposal it is nessesary urgently to work out and provide implementation of national standards and requirements for sewage sludge characteristics used as fertilizer in one package with technique for calculation of dose SS calculation premised for applying.

Development of modern technologies on WWTPs in Ukraine makes it possible to improve characteristics of sewage sludge as fertilizer and in such way decrease risks for the environment. For example thermal treatment (drying) will provide elimination of biological contamination of sewage sludge.

Energy production using sewing sludge as a fuel has to be only the fellow-way for Ukrainian waste water plants. In the country there are great reserves in energy saving and for providing on the industrial works and in municipal economy up-to-day technologies.

\section{REFERENCES}

[1] Lederer J., Rechberge H., 2010. Comparative goal-oriented assessment of conventional and alternative sewage sludge treatment options . Waste Management, 30, 1043-1056.

[2] Jiang J., Du X., Yang S., 2010. Analysis of the combustion of sewage sludge-derived fuel by a thermogravimetric method in China. Waste Management, 30, 1407-1413.

[3] Werther J., Ogada T.,1999. Sewage sludge combustion, Progress in Energy and Combustion Science, 25, 55-116.

[4] Diez Th., 1982. Landwirtschaftliche Klarschlammverwertung in Ballungsraumen dargestellt am Beispiel der Stadt Munchen. Z. fur Kulturtechnik und Flurbereinigung., 23, (3), 149-163. (In German).

[5] http://www.thestar.com/article/ (accessed September 26, 2010)

[6] Hall G.W., 1985. The Chicago experience in large scale land application. Bio Cycle, 26, (1), 38-40.

[7] http://www.iicmr.ru/precipitation.html (accessed September 08, 2010)

[8] http://www.esru.strath.ac.uk/EandE/ (accessed September 06, 2010)

[9] http://www.aces.edu/crd/publications/ANR-721.721.html. (accessed September 02, $\underline{2010)}$

[10] Bakulin S. M., 2010 Osadki stochnikh vod - udobreniya i biostimulyatory dekorativnikh kultur. (Municipal sewage sludge as fertilizers and biostimulators of decorative crops). CD- ROM. SIBICO International. Ltd. Moscow, June 2-4,2010.. (In Russian).

[11] Vostrova R. N., Lisitsin V. L., 2010. Utilizatsiya osadkov stochnikh vod pri rekultivatsii narushenykh zemel. (Utilisation of sewage sludge in process of destroyed land restoration). Ibid. (In Russian).

[12] Epoyan S. M., Korin'ko I. V., Karagyaur A.C., Stepanov O. V., 2010. Modulnaya ustanovka dlya povysheniya effectivnosti vodootbora s ilvykh ploshadok. (Modular installation for increasing of effectiveness of watertaking from sludge fields). Ibid. (In Russian).

[13] http://EUROPA.EU/legislation_summaries/index_en.htm (accessed September 22, 2010)

[14] http://www.britannica.com/EBchecked/topic/612921/Ukraine/30095/Soils

[15] Kharkivs'ka oblast u 2008 rotsi (statystichniy zbirnyk), 2009. (Kharkiv region in 2008, statistics. The main statistic administration in Kharkiv region, Kharkiv. (In Ukrainian).

[16] Shadrunova M., 2007. Estimation of agricultural technical equipment affect on soil compaction and erosion (MSc thesis, manuscript). Kharkiv, NAMEK. (In Russian). 
[17] Shetinin A. I., 2010. Elementnii sostav activnogo ila. (Element content of activated sludge). In: IWA specialist conference Water and Wastewater Treatment plants in Towns and Communities of the XXI Century: Technologies, Design and Operation. June 2-4, 2010, Moscow. CD- ROM. SIBICO International. Ltd. Moscow, June 2-4,2010. (In Russian).

[18] Suchkova N., Darakas E., Ganoulis J., 2010. Phytoremediation as a prospective method for rehabilitation of areas contaminated by long-term sewage sludge storage: A Ukrainian-Greek case study. Ecol. Eng. 36, 374-378.

[19] Suchkova, N., Vergeles, Y., 2007. From laboratory experiment to large-scale application-case studies of the phytoremediation of chemical agents of the sludge fields at Kharkiv Wastewater Treatment Plant, Ukraine. In: Kaczala, F., Juanga, J., Hogland, W., Marques, M., Vinrot, E. (Eds.), Proceedings of Kalmar Eco-Tech 07. Kalmar, Sweden, pp. 213-225

[20] Directive 86/278/EEC. Council Directive of 12 June 1986 Concerning the protection of the environment, and in particular of the soil, when sewage sludge is used in agriculture.

[21] State Standard GOST R 17.4.3.07 - 2001, 2001. Okhrana prirody. Pochvy. Trebovaniya $\mathrm{k}$ svoistvam osadkov stochnich vod pri ispol'zovanii ikh $\mathrm{v}$ kachestve udobrenii. (Environmental protection. Soils. Requirements on the properties of sewage sludge for their application as fertilizers).State Standardization and Metrology Committee, Moscow (In Russian).

[22] Technical Requirements TU 204 Ukrainy 76-93 "Dobryva z osadiv stichnyh vod",1994. (Standard of Ukraine "Fertilizer made from sewage sludge",Valid until 1998.). (In Ukrainian).

[23] Sanitary norms SANPiN 42-128-4433-87, 1987. Sanitarnie normy dopustimikh kontsentratsyy khimicheskikh veshestv $\mathrm{v}$ pochve.(Sanitary limits for concentration of chemical substances in soil.) Ministry of public health, USSR, Moscow. (In Russian).

[24] Dopovid'pro stan pryrodnogo navkolyshn'ogo seredovyshca u Kharkivs'kiy oblasti za 2008 rik, 2009. (Report about state of environment in Kharkiv region in year 2008). Regional Environmental Government in Kharkiv. (In Ukrainian). 